\title{
Octopus insularis (Cephalopoda: Octopodidae) on the tropical coast of Brazil: where it lives and what it eats
}

\author{
Allan Torrecilla Batista*, Tatiana Silva Leite
}

\author{
Laboratório de Bentos e Cefalópodes (LABECE), Departamento de Oceanografia e Limnologia (DOL), Universidade Federal do Rio \\ Grande do Norte (UFRN). \\ (Av. Sen. Dinarte Mariz, s/n, CEP: 59090-002, Natal, RN, Brazil) \\ *Corresponding author: allantb6@hotmail.com
}

\begin{abstract}
Octopus insularis is the dominant octopus in the shallow tropical waters of the coast and oceanic islands in the North and Northeast of Brazil. Is the abundance, distribution, habitat and diet of this species on the continent the same as in oceanic islands? These factors were evaluated in seeking these answers at two areas of occurrence of Octopus insularis on the coast of Rio Grande do Norte, Brazil. Three main types of habitats were described where the species is concentrated, being: Deep Reefs (Reefs of Risca) (>15 m), Flat Biogenic Plateaus (Restingas) (5-15 m) and Shallow Sedimentary Reefs (Pirangi reefs) $(<5 \mathrm{~m})$. An aggregate spatial distribution was verified, along with bathymetric segregation in which small individuals occupied shallow areas. Regarding diet, $O$. insularis consumed mainly crustaceans $(68 \%)$ in shallow reef areas, bivalves $(86 \%)$ in biogenic plateau areas, and gastropods $(33 \%)$ in deep reef areas. The characterization of new occurring habitats, such as the area of biogenic plateau, and changes in their diet due to habitat function have shown that $O$. insularis occupies a broader niche than has been described in literature to date, expanding our knowledge on the ecology and biology of this octopus species of economic interest.
\end{abstract}

Descriptors: Octopus insularis, Habitat, Octopus, Niche, Diet, Population.

\section{RESUMo}

Octopus insularis é o polvo dominante das águas rasas tropicais do litoral e ilhas oceânicas do Norte e Nordeste do Brasil. O habitat e dieta desta espécie seriam iguais no continente e nas ilhas oceânicas? Foram analisados distribuição e abundância dos polvos e a caracterização do habitat e dieta. Três tipos de habitat principais foram descritos para os locais onde a espécie se concentra, sendo eles: Recifes fundos (Riscas) ( $>15 \mathrm{~m}$ ), Platôs biogênicos planos (Restingas) (5-15 m) e Recifes sedimentares rasos (recifes de Pirangi) $(<5 \mathrm{~m})$. Verificou-se uma distribuição espacial agregada e uma segregação batimétrica na qual os indivíduos pequenos ocuparam as áreas rasas. Em relação à dieta, $O$. insularis consumiu principalmente crustáceos $(68 \%)$ nas áreas recifais rasas, bivalves $(86 \%)$ nas áreas do platô biogênico e gastrópodes (33\%) na área recifal funda. A caracterização de um novo habitat de ocorrência, tal como a área do platô biogênico, e a variação na sua dieta em função do habitat demonstram que o $O$. insularis ocupa um nicho mais amplo do que o descrito na literatura até o presente. Desta forma, o conhecimento sobre a ecologia e biologia desta espécie de interesse econômico para o Norte/Nordeste do Brasil tornou-se, assim, ampliado.

Descritores: Octopus insularis, Habitat, Polvo, Nicho, Dieta, População. 


\section{INTRODUCTION}

Octopus insularis (LEITE et al., 2008) is the dominant octopus of tropical shallow coastal and oceanic islands waters in the North and Northeast of Brazil. They are benthic animals found in tide pools up to $35 \mathrm{~m}$ deep (LEITE et al., 2008). Since this species was first described on oceanic islands, their ecology and biology have been studied more extensively in these regions, leaving a gap of knowledge regarding coastal areas.

In the Archipelago of Fernando de Noronha (AFN), their distribution, abundance and description of occurring habitats have been investigated. As a result, it was discovered that $O$. insularis occurs distributed in clusters in bedrock openings, with smaller octopuses being more abundant in shallow waters $(<5 \mathrm{~m})$ (LEITE et al., 2009c). Their food and foraging strategy were also investigated in this same environment, and a very diverse diet was observed, with more than 50 species of prey in food debris, mostly being crustaceans $(70 \%)$ (small crabs). Furthermore, $O$. insularis proved to be an opportunistic visual predator, adopting a predatory strategy called "saltatory search" (LEITE et al., 2009b).

A study at Rocas Atoll revealed that the shallow inshore ring areas serve as a nursery for $O$. insularis, due to the abundance of juvenile individuals found (BOUTH et al., 2011). Also, a study of the diversity of cephalopods in the Archipelago of Saint Peter and Saint Paul (ASPSP) registered $O$. insularis as the only species of benthic octopus found in depths up to $35 \mathrm{~m}$ (LEITE et al., 2009a), and most individuals were adults. Recently, its occurrence was also confirmed in the Archipelago of Trinidade located in the oceanic region of southeastern Brazil (LEITE et al., 2012), thus increasing the geographical range of this species. Octopus insularis were found in habitats with environments of reefs, rocky bottoms, pebbles, and gravel with or without algae; they were never found in completely sandy or muddy environments.

On the mainland, some recent studies have focused on aspects related to fishing and the population biology of $O$. insularis. This species is an important fishing resource in northeastern states as an alternative source of income for artisanal fishermen, especially during the lobster closed season. Since 2005 in the state of Ceará, profitable octopus fishing has been performed by long line lobster pots (BRAGA et al., 2007). Thus, in order to contribute to the management of this fishery resource, LIMA et al. (2014b) investigated the structure of the population and reproductive dynamics of the reef environment of Rio Grande do Norte (RN). The study found octopus in all gonadal maturity stages throughout the year; however, mature females were scarce, suggesting that they may migrate to deeper regions to achieve maturation and spawning. LIMA et al. (2014a) also described the gonadal development and reproductive strategy of this species, and despite having a gonadal development pattern similar to $O$. vulgaris, some differences were found, such as smaller size of maturation and lower fertility in $O$. insularis. Thus, this study will aim to verify the hypothesis that aspects of habitat use, abundance, distribution and food preferences of Octopus insularis on the continent are similar to those found in oceanic islands, since this species has been exploited by artisanal fisheries throughout the northeastern coast, having a great economic importance for the region.

\section{MATERIAL AND METHODS}

\section{STUDY AREA}

Octopus insularis ecology was studied at two areas of the Rio Grande do Norte coast. The first area is located $65 \mathrm{~km}$ from the capital, Natal, municipality of Rio do Fogo ( $\left.5^{\circ} 15^{\prime} \mathrm{S}-35^{\circ} 20^{\prime} \mathrm{W}\right)$, specifically the Environmental Protected Area of Coral Reefs (APARC), where the most productive octopus fishing of RN occurs ( $O$. insularis) (ANDRADE, 2015). Octopuses are caught in different habitats in this area, ranging from shallow reefs to deeper areas known as Risca, including sedimentary reefs combined with coralline algae, corals and vermetidae interspersed with sand and gravel patches. An area of low complexity biogenic plateaus was also studied in the region, known locally by fishermen as Restinga. These octopus and lobster fishing areas are quite exploited by local fishermen (Figure 1).

The second area is located on the southern coast of $\mathrm{RN}, 25 \mathrm{~km}$ from Natal, and is made up of coastal reefs formed by blocks of sandstone, calcareous algae, corals and rhodoliths $\left(6^{\circ} 00^{\prime} \mathrm{S}-35^{\circ} 06^{\prime} \mathrm{W}\right)$. This site is a tourist spot where recreational diving and fishing also occurs, including octopus fishing. This area is more shallow $(<5 \mathrm{~m})$ than the sampled areas on the north coast, thus increasing the diversity of $O$. insularis habitats studied.

The climate of the areas located on the eastern coast of $\mathrm{RN}$ is sub-humid, with average annual rainfall between 800 and $1200 \mathrm{~mm}$. According to the Koppen-Geiger classification it is equivalent to a rainy tropical climate 


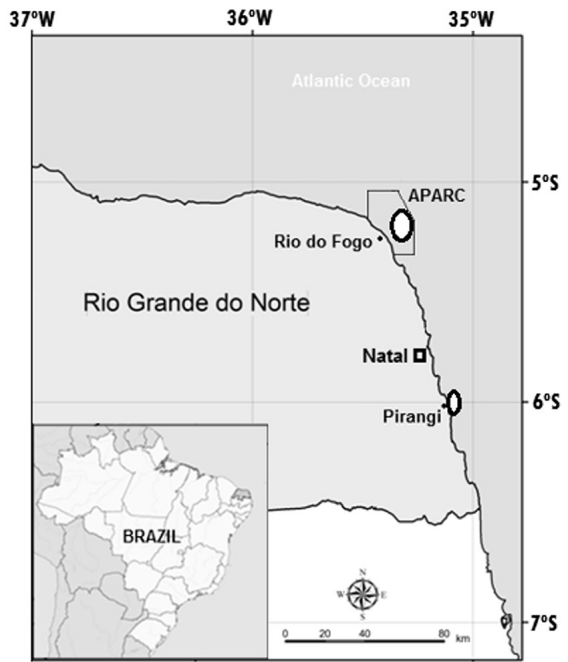

Figure 1. Study area, circles indicate sampling areas in APARC (Environmental Protected Area of Coral Reef) and Pirangi.

(Aw) with a dry winter, and the rainy season extends until July with annual average temperatures ranging between 22 and $27^{\circ} \mathrm{C}$.

\section{DATA COLLECTION}

Octopuses were observed in situ using visual search methods while SCUBA diving and snorkeling. Collections in the Environmental Protected Area of Coral Reef (APARC) were made in the periods of January, March and November 2010 and February 2011. In Pirangi, the dives were performed in the periods of March, April, and June 2011, and January and February 2012. Depths and temperature were recorded using dive computers and mercury thermometers. APARC sampling was carried out in the Restinga with intermediate depths $(5-15 \mathrm{~m})$, and in Risca (deeper reef areas, $>15 \mathrm{~m}$ ).

Evaluation of the density and spatial distribution of octopus was conducted in Pirangi, using an adaptation of the visual fixed square (FS) method (LEITE et al., 2009c), in a $50 \times 50 \mathrm{~m}\left(2500 \mathrm{~m}^{2}\right)$ area. This fixed square area was visually swept with the aid of a rectangle made from a PVC pipe, with smaller ( $2 \mathrm{~m}$ ) sides and nylon in the longer $(5 \mathrm{~m})$ sides, for easy transportation and handling. This gridded rectangle was flipped over after the search for holes in the area was finalized, so the search continued on until completing the total FS area (Figure 2).

The standardized Morisita dispersion index (Ip) was used in order to evaluate the spatial distribution (KREBS, 1999). The relative abundance of octopus at depths greater than $5 \mathrm{~m}$ was obtained through the Intensive Visual

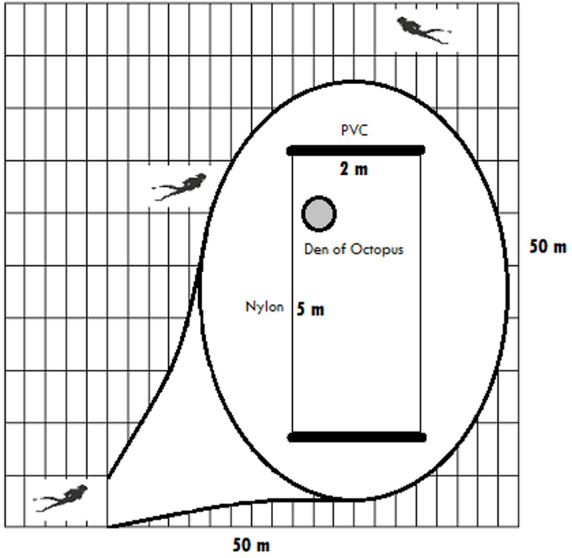

Figure 2. Sample design Fixed Square method (FS). Highlighted rectangle used to assist in the visual search for Octopus insularis dens and control the size of the sampled area.

Search method (IVS), which consists of an adaptation of the sampling technique called Roving diver (SCHMITT; SULLIVAN, 1996). This method allows for coverage of a larger area in less time while diving, being more appropriate due to the limited scuba diving time (see adaptation in LEITE et al., 2009c).

The octopuses found were classified into four size categories based on mantle length (ML) and interocular distances: Extra-Small (ES) ML < 50mm, Small (S) 50-80 $\mathrm{mm}$, Medium (M) 80-110 $\mathrm{mm}$ and Large (L) $>110 \mathrm{~mm}$. Morphometric relationships between mantle, arms, suckers and distance between the eyes facilitated visual classification of individuals in their dens. Octopus dens were classified into four types: Under Rock (UR) - octopus sheltered beneath rocks or other consolidated material such as coral, sponge, plateau reef, in sandy bottom; Rock (RO) - Octopus housed in holes in rock blocks $(>0.5 \mathrm{~m}$ in length); Reef Flat (RF) - Octopus housed in horizontal holes on reef plateaus, or other consolidated bottom; Vertical Rock (VR) - octopus nestled among rocks in orthogonal position relative to the surface of the water (LEITE et al., 2009c).

The habitats where occupied dens were found were characterized based on the depth, vegetation cover and structural complexity. The coverage of the substrate was recorded by the transecting points method (TPM) (MUNRO, 2013), which consists in logging the substrate coverage category located exactly at each $0.5 \mathrm{~m}$ point. Five TPM were conducted randomly in each area of $25 \mathrm{~m}$. The following substrate coverage categories were used: Sand (S) - unconsolidated sandy sediment; Gravel (GR) - fragments of unconsolidated material; 
Rock (R) - rocky blocks, pebbles; Rodolith (ROD) calcareous algae fragments of oval shape; Corals (CO) - hard or soft corals; Sponges (Sp) - Porifera species; Filamentous Algae (FA) - unbranched filamentous algae; Calcareous Algae (CA) - algae incrusting on hard bodies; and Branched Seaweed (BS) - seaweed with branches. After the TMP recordings, the structural complexity of habitats were analysed as determined by the surface roughness, den size and percentage of living coverage through the Habitat Assessment Score (HAS) proposed by GRATWICKE and SPEIGHT (2005).

Diets were characterized from the collection of food scraps left in front of the dens, such as carapaces, shells, and other bodies collected for later identification in the laboratory. Only newer materials, such as non-weathered debris or encrusted algae were not considered (MATHER, 1991). The identification of prey was conducted through specialized literature for molluscs (RIOS, 1994) and shellfish (MELO, 1996). Widths of shells and carapaces were measured with the aid of a caliper.

\section{STATISTICAL ANALYSES}

Pearson's chi-square test was used to check possible relationships between the categorical variables of: substrate and sampled area; size of octopus and type of den; size of octopus and depth; and size of octopus and diet. The density obtained in Fixed Square space $\left(2500 \mathrm{~m}^{2}\right)$ was expressed in individual $100 \mathrm{~m}^{-2}$. The relative abundance was expressed in number of octopuses found by the total diving time in each area (i-ividual time-1), and both sampled areas were compared using Student's $t$-test. One-way ANOVA was used followed by Tukey HSD test in order to test differences between the sizes of most consumed prey (shell width) in relation to octopus size category. Normality and homogeneity of data were tested by Kolmogorov and Levene tests, respectively (ZAR, 2010).

\section{RESULTS}

A total of 89 Octopus insularis individuals (12 ES, $26 \mathrm{~S}, 15 \mathrm{M}, 24 \mathrm{~L}$ and 12 non-classified) were found at total depths between 0.5 and $25 \mathrm{~m}$. Of this total, 71 were recorded during scuba diving (IVS method), and 17 on free snorkeling dives (Fixed Square method). Another two species of octopuses were identified in the study sites during this study, being Octopus hummelinck Adam (1936) and Amphioctopus burryi Voss (1950), and both were being eaten by $O$. insularis.

Regarding abundance, a density of 0.4 ind. per $100 \mathrm{~m}^{-2}$ was found in the shallow reefs of Pirangi, with a spatial aggregate distribution ( $\mathrm{Ip}>0$; Ip $=0.03$ ), higher than found to the oceanic island Fernando de Noronha, Rocas Atoll (Table 1). During Intensive Visual Search (IVS) in Rio do Fogo, 49 octopuses were found during 13.9 hours of diving in four sampling sites in the area of Restinga, resulting in an average of relative abundance of $3.2 \pm 0.8$ ind. h-1. In the deep reef, 32 octopuses were found in 7.8 hours of diving at five sampling sites, resulting in a relative abundance average of $2.7 \pm 1$ ind. h- 1 . Despite the relative abundance in Restinga being higher than in Risca, there were no significant differences between the areas (T-Test; $\mathrm{T}=0.7 ; \mathrm{df}=7 ; p=0.48$ ). These abundance values were also higher than found to Fernando de Noronha, and Trindade Archipelago (Table 2).

Regarding the habitats, substrate coverage between the Pirangi reef areas of Restinga and Risca showed significant differences $\left(\mathrm{X}^{2}=38.31, \mathrm{df}=8, p=6.58 \mathrm{e}-6\right)$. Pirangi presented primarily bedrock (blocks and fragments) with rhodoliths covered for the most part by Branched Seaweed (49\%). In the Restinga, the substrate was more homogeneous with little presence of solid bodies, composed of plateaus and sandy gravel, and the substrate cover is characterized by the following proportions: Sand (24\%), Gravel (22\%), Sponge (19\%) and Branched Seaweed (18\%). This different environment had not yet been previously described for $O$. insularis (Figure 3 and Table 1). In deeper reefs $(>15 \mathrm{~m})$, the substrate was formed by reef plateaus fragments with higher amounts of solids, with substrate formed primarily of Sand (31\%), Branched Seaweed (27\%) Gravel (12\%) and filamentous algae (10\%) (Figure 4).

HAS analysis indicated that the three evaluated areas were similar in relation to the size of the dens

Table 1. Descriptions of substrate, depth and HAS (Habitat Assessment Score) of sampled areas.

\begin{tabular}{|c|c|c|c|c|c|}
\hline \multirow{2}{*}{ Area } & \multirow{2}{*}{ Substrate } & \multirow{2}{*}{ Depth (m) } & \multicolumn{3}{|c|}{ HAS } \\
\hline & & & Roughness & Den size & Live cover \\
\hline Pirangi & Rocky (fragments and blocks), rhodoliths, algae and little sand. & $0-5$ & 3 & 2 & 4 \\
\hline Restinga & Sandy plateau with gravel and sponge, few hard bodies. & $5-15$ & 1 & 1 & 4 \\
\hline Risca & Small reefs between sandy bottom. & $>15$ & 2 & 2 & 4 \\
\hline
\end{tabular}


Table 2. Comparative of the environmental characteristics among continental and oceanic areas: Rio do Fogo (RF), Pirangi (PR), Rocas Atoll (RA), Fernando de Noronha archipelago (AFN), Saint Peter and Saint Paul archipelago (ASPSP), and Trindade and Martim Vaz Archipelago (ATMV). Octopus size: Extra-small (ES), Small (S), Medium (M), Large (L); dens type: Under Rock (UR), Rock (RO), Reef Plateau (RP), Vertical Rock (VR).

\begin{tabular}{|c|c|c|c|c|c|c|c|c|}
\hline $\begin{array}{l}\text { Sampled } \\
\text { sites }\end{array}$ & Region & Lat/Log & $\begin{array}{l}\text { General description of } \\
\text { the habitats }\end{array}$ & $\begin{array}{l}\text { Main prey } \\
\text { species }\end{array}$ & $\begin{array}{l}\text { Octopus } \\
\text { size versus } \\
\text { den type }\end{array}$ & $\begin{array}{l}\text { Population } \\
\text { mean } \\
\text { abundance }\end{array}$ & $\begin{array}{l}\text { Size of } \\
\text { main prey }\end{array}$ & Reference \\
\hline $\mathrm{RF}$ & $\begin{array}{l}\text { Continental } \\
\text { shelf }\end{array}$ & $\begin{array}{l}05^{\circ} 38^{\prime} \mathrm{S} / \\
35^{\circ} 25^{\prime} \mathrm{W}\end{array}$ & $\begin{array}{c}\text { Sandy patches, } \\
\text { seagrass, algae patches, } \\
\text { sandstone reef, } \\
\text { rocky, coral reefs, flat } \\
\text { biogenic reef, rubble, } \\
\text { muddy }\end{array}$ & $\begin{array}{l}\text { A. notabilis } \\
\text { (Bivalvia) }\end{array}$ & $\begin{array}{c}\text { M occupied } \\
\text { dens in RP. } \\
\text { ES and L } \\
\text { not occu- } \\
\text { pied VR. }\end{array}$ & $\begin{array}{l}\text { 2.7-3.8 } \\
\text { ind./hour }\end{array}$ & $24-30 \mathrm{~mm}$ & This study \\
\hline PR & $\begin{array}{l}\text { Continental } \\
\text { shelf }\end{array}$ & $\begin{array}{c}58^{\prime} 37^{\prime \prime} \mathrm{S} / \\
35^{\circ} 6^{\prime} 41^{\prime \prime} \mathrm{W}\end{array}$ & $\begin{array}{l}\text { Intertidal rocky reef, } \\
\text { coral reef, sandy, } \\
\text { rubble, algae patches, } \\
\text { tide pools }\end{array}$ & $\begin{array}{c}X . \\
\text { denticulatus } \\
\text { (Crustacea) }\end{array}$ & $\begin{array}{c}\text { ES occupied } \\
\text { dens in UR } \\
\text { and none in } \\
\text { VR. }\end{array}$ & $\begin{array}{c}0.4 \\
\text { ind. } / 100 \mathrm{~m}^{2}\end{array}$ & $13-25 \mathrm{~mm}$ & This study \\
\hline $\mathrm{AR}$ & $\begin{array}{l}\text { Oceanic } \\
\text { Island }\end{array}$ & $\begin{array}{l}03^{\circ} 50^{\prime} 30^{\prime \prime} \mathrm{S} / \\
33^{\circ} 49^{\prime} 29^{\prime} \mathrm{W}\end{array}$ & $\begin{array}{l}\text { Intertidal rocky reef, } \\
\text { coral reef, tide pools, } \\
\text { sandy, algae patches }\end{array}$ & $\begin{array}{c}X . \\
\text { denticulatus } \\
\text { (Crustacea) }\end{array}$ & $\begin{array}{l}\text { RP was the } \\
\text { most occu- } \\
\text { pied and VR } \\
\text { the least. }\end{array}$ & $\begin{array}{c}0.2 \\
\text { ind. } / 100 \mathrm{~m}^{2}\end{array}$ & $6-20 \mathrm{~mm}$ & $\begin{array}{l}\text { BOUTH et } \\
\text { al., } 2011\end{array}$ \\
\hline AFN & $\begin{array}{l}\text { Oceanic } \\
\text { Island }\end{array}$ & $\begin{array}{l}03^{\circ} 51^{\prime} \mathrm{S} / \\
32^{\circ} 25^{\prime} \mathrm{W}\end{array}$ & $\begin{array}{l}\text { Intertidal rocky reef, } \\
\text { rocky reef, rocky, coral } \\
\text { reef, algae patches, } \\
\text { sandy, muddy, rubble }\end{array}$ & $\begin{array}{c}\text { Pitho sp. } \\
\text { (Crustacea) }\end{array}$ & $\begin{array}{c}\text { ES occupied } \\
\text { dens in UR } \\
\text { and RF. And } \\
\text { none in VR. }\end{array}$ & $\begin{array}{c}0.1 \\
\text { ind./100 } \mathrm{m}^{2} \\
1.3 \mathrm{ind} / \\
\text { hour }\end{array}$ & $10-24 \mathrm{~mm}$ & $\begin{array}{l}\text { LEITE et } \\
\text { al., 2009c }\end{array}$ \\
\hline ASPSP & $\begin{array}{l}\text { Oceanic } \\
\text { Island }\end{array}$ & $\begin{array}{l}00^{\circ} 56^{\prime} \mathrm{N} / \\
29^{\circ} 22^{\prime} \mathrm{W}\end{array}$ & $\begin{array}{l}\text { Rocky reef, algae } \\
\text { patches, rubble }\end{array}$ & $\begin{array}{l}\text { M. forceps } \\
\text { (Crustacea) }\end{array}$ & - & $\begin{array}{c}<0.0001 \\
\text { ind. } / 100 \\
\mathrm{~m}^{2}\end{array}$ & $9-16 \mathrm{~mm}$ & $\begin{array}{l}\text { LEITE et } \\
\text { al., } 2016\end{array}$ \\
\hline ATMV & $\begin{array}{l}\text { Oceanic } \\
\text { Island }\end{array}$ & $\begin{array}{l}20^{\circ} 30^{\prime} \mathrm{S} / \\
29^{\circ} 20^{\prime} \mathrm{W}\end{array}$ & $\begin{array}{l}\text { Rocky reef, intertidal } \\
\text { rocky bed, coral reef, } \\
\text { algae patches, rubble }\end{array}$ & $\begin{array}{c}\text { Lithopoma } \\
\text { sp. } \\
\text { (Gastropoda) }\end{array}$ & - & $\begin{array}{l}1.5 \text { ind./ } \\
\text { hour }\end{array}$ & $25-45 \mathrm{~mm}$ & $\begin{array}{l}\text { LEITE et } \\
\text { al., } 2016\end{array}$ \\
\hline
\end{tabular}

$(\mathrm{HAS}=2)$ and percentage of live coverage (HAS = 4), which represents $40-79 \%$ of live coverage. Pirangi had the highest roughness score (HAS $=3$ ); and Restinga had the lowest $(\mathrm{HAS}=1)$, which reflects the low structural heterogeneity of the substrate, with the latter also featuring the smallest den sizes $(\mathrm{HAS}=1)$. Deep reef roughness and den size was slightly larger than those in the area of Restinga, both with a score of 2 (Table 1).

\section{ENVIRONMENTAL VARIABLES VERSUS OCTOPUS SIZES}

When analyzing the relationship between environmental variables and the sizes of octopus, the overall result was that the most used type of den was Reef Flat (39\% of cases), followed by Under Rock (36\%), and the least attractive type was Vertical Rock, with only $3 \%$. A significant relationship between the size of the octopus and type of den was found $\left(\mathrm{X}^{2}=97.03, \mathrm{df}=9, p=2.2 \mathrm{e}-16\right)$, with Medium size occupying reef flat dens, and Large and Extra Small animals not been found in Vertical Rock dens (Figure 5). The octopus dens preference at the continental shelf was very similar to the oceanic islands, showing a similarity at habitat of occurrence (Table 2).

Regarding depth, there was a significant relationship between this variable and the size of octopus, with a trend towards larger individuals inhabiting deeper areas $\left(\mathrm{X}^{2}=14.38, \mathrm{df}=6, p=0.025\right)$. Large individuals did not occur in shallow waters $(<5 \mathrm{~m})$, and were more abundant in intermediate areas (5-15 m). Conversely, Extra Small individuals were not found in deeper areas $(>15 \mathrm{~m})$ (Figure 6).

\section{DIETS}

A total of 37 food items were found in 12 dens in the shallow reefs of Pirangi. Crustaceans were the most consumed items, with 7 species $(68.4 \%, \mathrm{n}=26)$, followed by 3 species of gastropods, $(15.8 \%, n=6)$, and 2 species of bivalves $(15.8 \%, \mathrm{n}=6)$. More than half of the items consumed in this area $(71.1 \%, \mathrm{n}=27)$ were comprised of 5 species; Crustacea: Xanthodius denticulatus White (1848) (26.3\%), Pitho sp. Bell (1835) (18.4\%) and Mithrax forceps A. Milne-Edwards (1875) (7.9\%); Bivalvia: Arca 


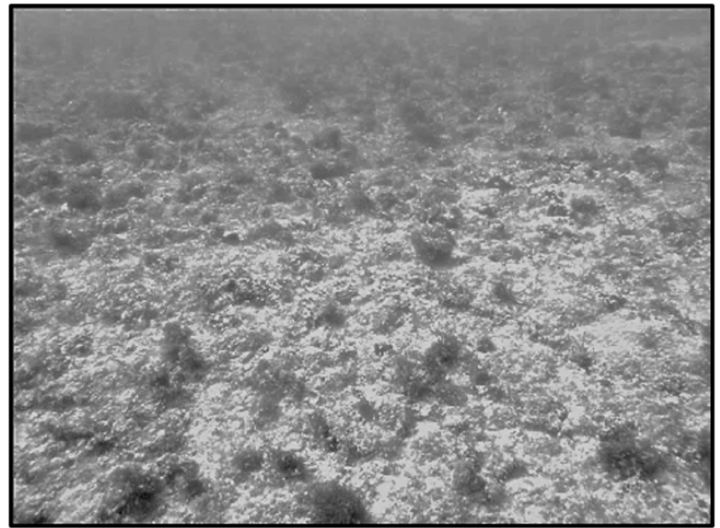

Figure 3. New habitat occurrence for Octopus insularis. Called Restinga with depth between 5 and $15 \mathrm{~m}$, inside the Environmental Protection Area of Coral Reefs (APARC), Rio do Fogo/RN, Brazil.

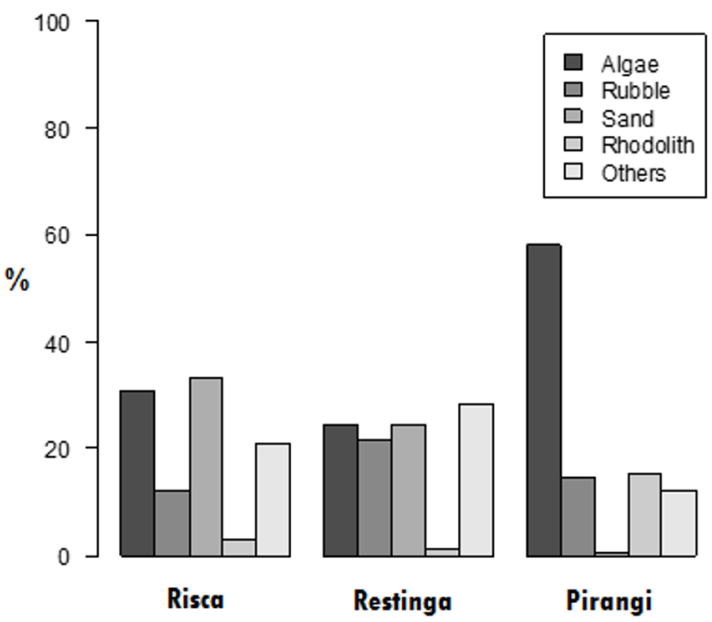

Figure 4. Percentage of substrate coverage in the sampled areas: Pirangi - shallow sedimentary reef; Restinga - biogenic plateaus; Risca Reefs. Legend: BS - branched seaweed; S - Sand; ROD - Rodolith; Gr - Gravel; FA - filamentous algae; Others - less frequent categories.

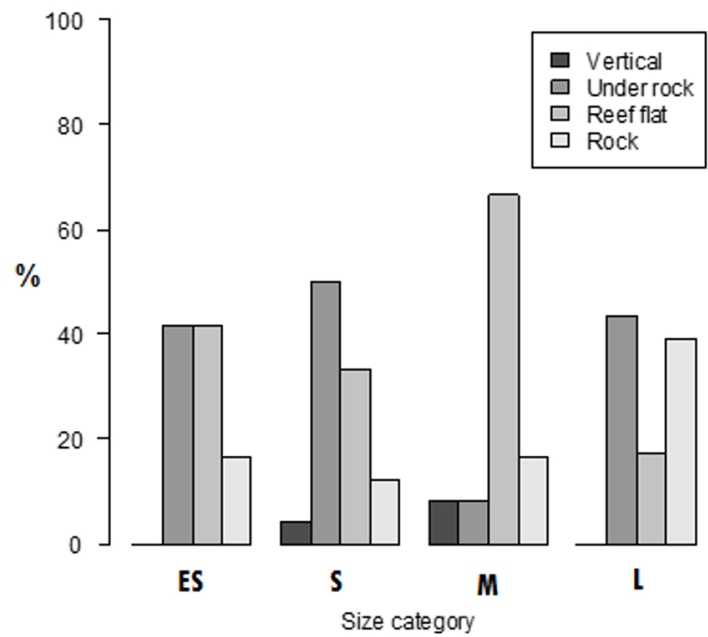

Figure 5. Percentage of occurrence of den types across Octopus insularis size categories. Extra-Small $(E S, n=12)$, Small $(S, n=24)$, Medium (M, $n=12)$ and Large $(L, n=23)$.

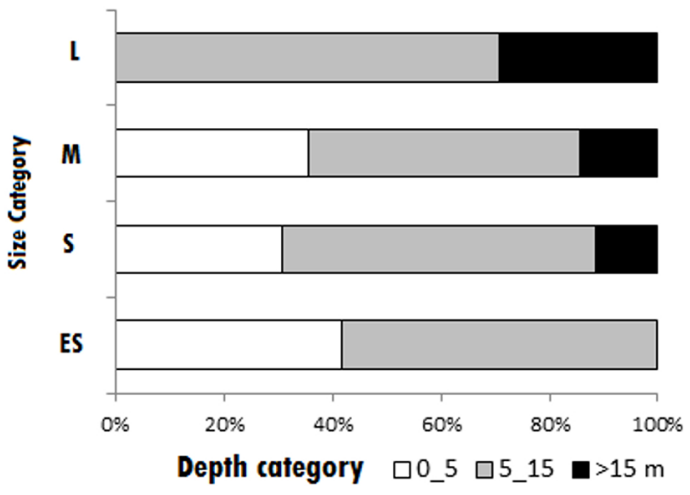

Figure 6. Percentage occurrence of Octopus insularis size categories across depth categories. Extra-Small (ES, $\mathrm{n}=12)$, Small $(\mathrm{S}, \mathrm{n}=26)$, Medium (M, $n=14)$ and Large $(L, n=24)$.

imbricata Bruguière (1789) (10.5\%) and Gastropod: Pissania pusio Linnaeus (1758) (7.9\%) (Table 3). The main crustaceans species found at the dens remains at this continental reef correspond with the main prey found at Rocas Atoll, Fernando de Noronha and Saint Peter Archipelago (Table 2).

In Restinga, 379 food items were collected in 30 dens, where bivalves were the most consumed items $(91 \%, \mathrm{n}=43)$, with 15 species, followed by Gastropod $(0.05 \%, \mathrm{n}=19)$, with 10 species, and Crustacea $(0.04 \%, \mathrm{n}=16)$ with 5 species. Among the most consumed items, 5 species of bivalve accounted for over $70 \%$, Anadara notabilis Roding (1798) (32\%) occurred in 77\% of sampled dens; Laevicardium brasilianum Lamarck (1819) (15\%) were found in 50\% of dens; Mactra fragilis Gmelin (1791) (13\%) occurred in 57\% of dens; and Modiolus americanos Leach (1815) (7\%) found in 43\% of dens. In this area, we observed a large (L) O. insularis feeding on an octopus of a different species, Amphioctopus burryi Voss (1950).

At Risca, 77 food items were collected in 8 dens; bivalves were the most consumed items $(59 \%, \mathrm{n}=45)$ with 11 species, followed by Gastropods $(33 \%, \mathrm{n}=25)$ with 5 species, and Crustacea $(18 \%, \mathrm{n}=14)$ with 6 species. Among the most consumed items, the gastropod Cypraea sp. was the first $(20 \%)$ and it was found in half $(50 \%)$ of the analyzed dens, followed by bivalves Ventricolaria rigida Dillwyn (1817) (12\%) occurring in 37\% of dens, A. notabilis and Lima lima Linnaeus (1758) (8\%) and Trachycardium magnum Linnaeus (1758) (6.6\%) found in $25 \%$ of dens, and the Crustacean M. forceps $(6.6 \%)$ was found in $62 \%$ of the sampled dens (Table 3 ). In this area we observed a large (L) $O$. insularis feeding on an Octopus hummelinck Adam (1936). 
Table 3. Prey of $O$. insularis ( $\mathrm{n}$ and $\%$, representing $1 \%$ or more of prey consumed) found in middens/debris at Risca, Restinga and Pirangi, between 2010 and 2011.

\begin{tabular}{|c|c|c|c|}
\hline Prey species & $\begin{array}{c}\text { Risca } \\
(\mathrm{n}=77)\end{array}$ & $\begin{array}{l}\text { Restinga } \\
(\mathrm{n}=379)\end{array}$ & $\begin{array}{l}\text { Pirangi } \\
(\mathrm{n}=12)\end{array}$ \\
\hline \multicolumn{4}{|l|}{ Bivalvia } \\
\hline Ventricolaria rigida & $9(11.8)$ & $15(4.0)$ & - \\
\hline Anadara notabilis & $6(7.9)$ & $123(32.5)$ & - \\
\hline Lima lima & $6(7.9)$ & $14(3.7)$ & - \\
\hline Trachycardium magnum & $5(6.6)$ & $23(6.1)$ & - \\
\hline Mactra fragilis & $3(3.9)$ & $49(13.0)$ & - \\
\hline Modiolus americanus & $3(3.9)$ & $28(7.4)$ & - \\
\hline Arca imbricata & $2(2.6)$ & - & $4(10.5)$ \\
\hline Laevicardium brasilianum & $1(1.3)$ & $55(14.6)$ & - \\
\hline Papyridea sp. & $1(1.3)$ & $7(1.9)$ & - \\
\hline Pinna cornea & $1(1.3)$ & - & - \\
\hline Semele sp. & - & $18(4.8)$ & $2(5.3)$ \\
\hline Papyridea sp. & - & $7(1.9)$ & - \\
\hline \multicolumn{4}{|l|}{ Gastropod } \\
\hline Cypraea sp. & $20(26.3)$ & $10(2.6)$ & - \\
\hline Murexiella sp. & $2(2.6)$ & - & - \\
\hline Bullata matthewsi & $1(1.3)$ & - & - \\
\hline Columbella mercatoria & $1(1.3)$ & - & - \\
\hline Erosaria acicularis & $1(1.3)$ & - & - \\
\hline Pissania pusio & - & - & $3(7.9)$ \\
\hline Fissurela sp. & - & - & $2(5.3)$ \\
\hline Diadora sp. & - & - & $1(2.6)$ \\
\hline \multicolumn{4}{|l|}{ Crustacea } \\
\hline Mithrax forceps & $5(6.6)$ & $6(1.6)$ & $3(7.9)$ \\
\hline Xhantodius denticulatus & $3(3.9)$ & - & $10(26.3)$ \\
\hline Callapa gallus & $2(2.6)$ & - & - \\
\hline Chorinus heros & $2(2.6)$ & - & - \\
\hline Mithrax tortugae & $1(1.3)$ & $7(1.9)$ & - \\
\hline Pitho sp. & $1(1.3)$ & - & $7(18.4)$ \\
\hline Acanthonyx scutiformis & - & - & $2(5.3)$ \\
\hline Epialtus brasiliensis & - & - & $2(5.3)$ \\
\hline Mithrax tortugae & - & - & $1(2.6)$ \\
\hline Microphrys sp. & - & - & $1(2.6)$ \\
\hline \multicolumn{4}{|l|}{ Cephalopoda } \\
\hline Octopus hummelinck & $1(1.3)$ & - & - \\
\hline
\end{tabular}

When we evaluate the composition of the large groups of bivalves, Gastropod and Crustacea in the diet of octopus, we find that these have different proportions amongst the three areas $\left(\mathrm{X}^{2}=213.42, \mathrm{df}=4, p=2.2 \mathrm{e}-16\right)$. In Pirangi, $68 \%$ of the consumed items were crustaceans, being small decapods; followed in equal proportions by $16 \%$ bivalves and gastropods. At Restinga, the diet consisted almost entirely of bivalves (91\%), and to a lesser extent gastropod (5\%) and crustaceans ( $4 \%$ ). At Risca, the proportion of taxons was more balanced, however, as half of the items consumed were bivalves (49\%), followed by gastropods $(33 \%)$, and crustaceans at a lesser amount (18\%) (Figure 7).
The prey species found in dens remains at Risca e Restinga did not correspond the one already described for O. insularis at the oceanic islands (Table 3), indicating an increase of its diet preference toward the continent.

Regarding the variation in the size of the prey among the octopus size categories, we found that the width of the shells of the most consumed species A. notabilis varied significantly (ANOVA, $\mathrm{F}=3.9 ; \mathrm{df}=3 ; p=0.009$ ) among the Exta Small $(\mathrm{n}=32 ; 23.7 \pm 4.6 \mathrm{~mm})$ and Large $(\mathrm{n}=24$; $28.6 \pm 5.1 \mathrm{~mm}$ ) categories (Tukey, $\mathrm{MS}=35.01 ; \mathrm{df}=104$; $p=0.017)$. The diet composition among size categories were also different $\left(\mathrm{X}^{2}=29.79, \mathrm{df}=6, p=4.3 \mathrm{e}-5\right)$. Bivalves were the most consumed items among all classes. 
Extra small individuals did not consume gastropods,
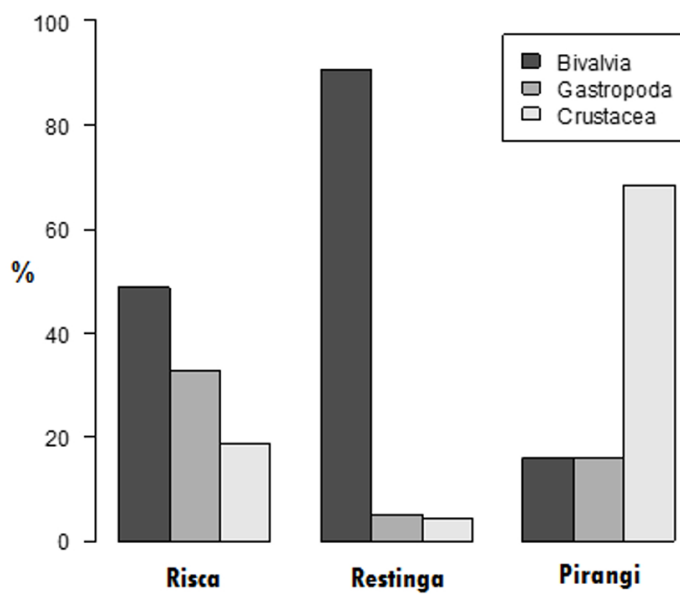

Figure 7. Percentage of Bivalvia, Gastropod and Crustacea prey categories, found in middens/debris of Octopus insularis in the sampled areas of Pirangi, Restinga and Risca $(n=492)$.

however larger individuals had the highest consumption of gastropods (16\%) (Figure 8).

\section{DISCUSSION}

Some distinct features were found in this study when comparing the niches occupied by the population of Octopus insularis in the state of $\mathrm{RN}$ with the populations of oceanic islands in the Northeast. These include expansion of habitats and diets, and other similarities, such as the population density, clustered distribution pattern in rocky bottoms and bathymetric segregation in relation to body size categories (see Table 2).

One of the most important results of this study was the occurrence of $O$. insularis in the biogenic plateau, known locally by local octopus fishermen as 'Restinga', a completely different habitat from previously recorded habitats for the species (LEITE et al., 2009c; BOUTH et al., 2011). Restinga is a plateau formed by both non-biogenic material (sand, gravel and rocks), as well as biogenic material, primarily sponges and algae. It is interesting to note that this environment has mild heterogeneity, low roughness, and a lower number of dens when compared to reef areas, where one might expect a lower abundance of octopus as these are considered important requirements for the occurrence of octopus (ANDERSON, 1997; KATSANEVAKIS; VERRIOPOULOS, 2004a). However, this region had abundances similar to those found in the Fernando de Noronha national reef park, stressing the

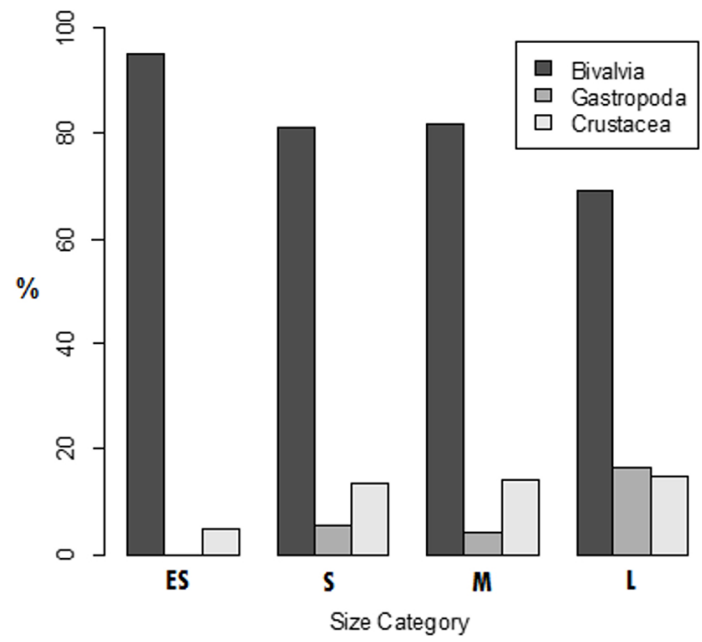

Figure 8. Percentage of Bivalvia, Gastropod and Crustacea prey categories across Octopus insularis size categories. Extra-Small $(\mathrm{ES}, \mathrm{n}=92)$, Small $(\mathrm{S}, \mathrm{n}=132)$, Medium $(\mathrm{M}, \mathrm{n}=30)$ and Large (L, $\mathrm{n}=148)$.

importance of the environment for the population of octopuses in this region.

Restinga is not a completely sandy environment, which in fact would reduce the density of these mollusks in the environment, but it presents extensions than can be dug out by octopuses for building their shelters, or by increasing existing cracks/gaps in the plateau. In Rodas Inlet, Portugal, in an environment similar to the Restinga with a depth between 5 and 21m, GUERRA et al. (2014) found $O$. vulgaris dens built on sand, reinforced with bivalve shells, and suggested that more than half of the observed dens are permanent, being occupied by several generations of octopus. Furthermore, the density of 0.34 ind. per $100 \mathrm{~m}^{-2}$, and the clustered aggregation pattern are similar to those found in reef environments with high availability of dens such as in Pirangi.

The population density of 0.40 ind. per $100 \mathrm{~m}^{-2}$ found in the area of Pirangi, and 3.2 and 2.7 ind. $\mathrm{h}^{-1}$ (duration of dive) in Rio do Fogo were also similar to those found in Fernando de Noronha of 0.12 to 0.88 ind. per $100 \mathrm{~m}^{-2}$, and mean of 1.34ind. $\mathrm{h}^{-1}$ (LEITE et al., 2009c) in rocky and reef habitats, and at Rocas Atoll on reef plateaus (0.12 to 0.36 ind. per $100 \mathrm{~m}^{-2}$ ) (BOUTH et al., 2011). Such densities show that $O$. insularis is also abundant and dominant in shallow and deep reefs in the coastal waters of northeastern Brazil. Such densities are also similar to those found for other species and in other environments. For example, $O$. vulgaris in sandy shore environments in Greece, with results between 0 and 0.68 ind. per $100 \mathrm{~m}^{-2}$ (KATSANEVAKIS; VERRIOPOULOS, 2004b), and for Enteroctopus dofleini, 
in Alaska, between 0 and 0.25 ind. per $100 \mathrm{~m}^{-2}$ (SCHEEL, 2002). These different densities may be associated with different resources and conditions that the habitats present, such as availability of shelter and food (KATSANEVAKIS; VERRIOPOULOS, 2004a).

The clustered distribution pattern of $O$. insularis found in our analysis was also found by LEITE et al. (2009c) in Fernando de Noronha, and for BOUTH et al. (2011) at Rocas Atoll, and for other species, such as Octopus joubini in sandy environments (MATHER, 1982), Octopus tetricus in reef environments (ANDERSON, 1997), and also for Octopus vulgaris in sandy environments (GUERRA et al., 2014). In this study, clustered distribution was observed at the edge of a reef at a depth of $0-2 \mathrm{~m}$, with lots of rocks, gravel and dens available, representing an attraction for octopuses. The heterogeneity of habitat such as edge reefs, plateaus, and gravel in sandy environments are important factors in the distribution of benthic octopuses because they provide the shelter needed for them (ANDERSON, 1997; FORSYTHE; HANLON, 1997; KATSANEVAKIS; VERRIOPOULOS, 2004a). Aggregation due to reproductive demands was not a justifying factor for the aggregation in the present study (HUFFARD et al., 2008; LEITE et al., 2009c). The absence of this relationship is probably related to the fact of not having taken into account the distances among dens in the deeper areas of study, where one would expect to find adult animals. The aggregation evaluation was only performed in the shallow reefs of Pirangi, which more resembled a nursery area in the shallow waters of Rocas Atoll due to the high amount of juvenile animals.

Similar to LEITE et al. (2009c) study in Fernando de Noronha where octopuses (Extra Small) had an occupancy preference for horizontal dens in rocky and reef beds, octopuses found on the $\mathrm{RN}$ coast also showed preference for theirs types of dens. The variety and reduced amount of dens with few solids available in the environment (e.g. rocks blocks) might be an explanatory reason, since the Reef Flat and Under Rock types of dens were dens more occupied by all sizes. Small octopuses also preferred the shallower waters, similar to that found on oceanic islands. Compared with species of temperate waters, the bathymetric segregation of $O$. vulgaris sizes in the Mediterranean was found only when analyzed in different seasons. The smaller individuals were found in summer when the temperature is higher, while in the opposite season of winter, larger individuals were more abundant (KATSANEVAKIS; VERRIOPOULOS, 2006).
Some abiotic factors such as temperature and brightness can explain this spatial segregation between small and large individuals. Provided there is food available, temperature is a major factor affecting the growth rate of cephalopods (FORSYTHE; VAN HEUKELEM, 1987). Larger animals are stimulated to search for less warmer water at greater depth, thereby reducing the energy cost of a warmer metabolism, and on the other hand, smaller animals seek shallower areas in order to accelerate their growth rates, making them less vulnerable to predation (SCHMIDT-NIELSEN, 1996). In addition, the brightness in the environment can delay sexual maturation in cephalopods due to inhibiting the optical gland responsible for maturation (O'DOR; WELLS, 1978). Thus, the large ones found in the deeper areas may grow more slowly and reach sexual maturity faster. This information indirectly shows us a migration of the larger individuals to deeper areas.

Also in relation to abiotic factors affecting the distribution of this species, AMADO et al. (2015) recently found significant differences in the physiology of $O$. insularis, with the latter being a more euryhaline species when compared to $O$. vulgaris. This ability to withstand salinity changes either up or down may help explain the dominance of $O$. insularis in shallow tropical waters, where salinity can reach up to $34 \mathrm{ppm}$ in pools of coastal reefs of tides, where $O$. insularis juveniles were found in this study. Another important difference in the niche occupied by $O$. insularis on the continent compared to oceanic islands was the expansion of food preference. While the populations of Fernando de Noronha and at Rocas Atoll mostly consumed ( $>70 \%) 4$ and 5 species of small crabs (LEITE et al., 2009b; BOUTH et al., 2011), the diet of the octopuses at Rio do Fogo consisted largely $(>80 \%)$ of bivalve mollusks, and in all size categories as the main food items consumed in this region. This shift in food preference, of crustaceans to bivalves, appears to be strongly associated with the availability of prey in the habitat. A dominance of bivalves in the $O$. vulgaris diet in a sandy environment was also found in Portugal (GUERRA et al., 2014).

Despite this shift in food preference of crustaceans for bivalves, as well as the presence of few species in the diet in general, a relatively small size of the prey, and little variation of their size relative to the size of the octopus, there was continued evidence present that the continental $O$. insularis uses the same foraging strategy, thereby minimizing predator time (LEITE et al., 2009b; LEITE 
et al., 2016). The occurrence of unusual species in the $O$. insularis diet such as two species of small octopus found at Rio do Fogo, and also fish and turtles points to the opportunism of this predator, a well-known feature in this mollusk group.

The expansion of the diet described for $O$. insularis on the coast of Rio Grande do Norte highlights the need to investigate the ecology of this species, and strengthen the adaptability of these mollusks to different types of environments. This type of study is always necessary, especially when it is a commercially exploited species. Its abundance and distribution characteristics, as well as its bathymetric segregation being similar to the ones found on oceanic islands appear to be general ecological characteristics of the species. This information provides adequate support for the management and exploitation of $O$. insularis, and also for the coastal region, such as to protect shallow areas to increase the chances of juveniles surviving to reach adulthood, as proposed by LEITE et al. (2009a) for Fernando de Noronha; and to expand pot fishing in little explored regions with great fishing potential.

\section{ACKNOWLEDGEMENTS}

We would like to thank the members of the research laboratories (LABECE) for their help with the various dives and analysis; the Rio do Fogo fishermen for leading us to dive points with their boats, and their shared knowledge; the Federal University of Rio Grande do Norte (UFRN), the Brazilian National Research Council (CNPq) Project: 559863/2008-0 and the Coordination for Higher Education Personnel Improvement (CAPES) for logistical and financial support.

\section{REFERENCES}

AMADO, E. M.; SOUZA-BASTOS, L. R.; VIDAL, E. A. G.; LEITE, T. S.; FREIRE, C. A. Different abilities to regulate tissue hydration upon osmotic challenge in vitro, in the cephalopods Octopus vulgaris and O. insularis. Mar. Freshw. Behav. Physiol., v. 48, n. 3, p. 205-211, 2015.

ANDERSON, T. J. Habitat selection and shelter use by Octopus tetricus. Mar. Ecol Prog. Ser., v. 150, p. 137-148, 1997.

BOUTH, H. F.; LEITE, T. S.; LIMA, F. D.; OLIVEIRA, J. E. L. Atol das Rocas: an oasis for Octopus insularis juveniles (Cephalopoda: Octopodidae). Zoologia, v. 28, n. 1, p. 45-52, 2011.

BRAGA, M. S. C.; MARINHO, R. A.; BATISTA, B. B.; ROCHA, E. P. Histórico e descrição da desca do polvo, Octopus cf vulgaris, com potes, no estado do Ceará. Arq. Ciênc. Mar, v. 40, n. 2, p. 5-13, 2007.
FORSYTHE, J. W.; VAN HEUKELEM, W. F. Growth. In: BOYLE, P. R. (Ed.). Chephalopods life cycles. London: Academic Press, 1987. p. 135-156.

FORSYTHE, J. W.; HANLON, R. T. Foraging and associated behavior by Octopus cyanea Gray, 1849 on a coral atoll, French Polynesia. J. Exp. Mar. Biol. Ecol., v. 209, n. 1-2, p. 15-31, 1997.

GRATWICKE, B.; SPEIGHT, M. R. The relationship between fish species richness, abundance and habitat complexity in a range of shallow tropical marine habitats. J. Fish Biol., v. 66, n. 3, p. 650-667, 2005.

GUERRA, A.; HERNÁNDEZ-URCERA, J.; GARCI, M. E.; SESTELO, M.; REGUEIRA, M.; GONZÁLEZ, A. F.; CABANELLAS-REBOREDO, M.; CALVO-MANAZZA, M.; MORALES-NIN, B. Dwellers in dens on sandy bottoms: Ecological and behavioural traits of Octopus vulgaris. Sci. Mar., v. 78, n. 3, p. 405-414, 2014.

HUFFARD, C. L.; CALDWELL, R. L.; BONEKA, F. Mating behavior of Abdopus aculeatus (d'Orbigny 1834) (Cephalopoda: Octopodidae) in the wild. Mar. Biol., v. 154, n. 2, p. 353-362, 2008.

KATSANEVAKIS, S.; VERRIOPOULOS, G. Den ecology of Octopus vulgaris Cuvier, 1797, on soft sediment: availability and types of shelter. Sci. Mar., v. 68, n. 1, p. 147-157, 2004a.

KATSANEVAKIS, S.; VERRIOPOULOS, G. Abundance of Octopus vulgaris on soft sediment. Sci. Mar., v. 68, n. 4, p. $553-560,2004 \mathrm{~b}$

KATSANEVAKIS, S.; VERRIOPOULOS, G. Seasonal population dynamics of Octopus vulgaris in the eastern Mediterranean. J. Mar. Sci., v. 63, n. 1, p. 151-160, 2006.

KREBS, C. J. Ecological Methodology. 2nd ed. San Francisco: Benjamin Cummings. 1999.

LEITE, T. S.; HAIMOVICI, M.; MOLINA, W.; WARNKE, K. Morphological and genetic description of Octopus insularis, a new cryptic species in the Octopus vulgaris complex (Cephalopoda: Octopodidae) from the tropical southwestern Atlantic. J. Mollus. Stud., v. 74, n. 1, p. 63-74, 2008.

LEITE, T. S.; ANDRADE, L. C. A.; HAIMOVICI, M.; AGUIAR, R. S.; LINS-OLIVEIRA, J. E. Lulas e polvos. In: HAZIN, F. H. V. (Ed.). O Arquipélago São Pedro e São Paulo: 10 anos Estação Científica. Brasília: SECIRM, 2009a. p. 186-193.

LEITE, T. S.; HAIMOVICI, M.; MATHER, J. Octopus insularis (Octopodidae), evidences of a specialized predator and a time-minimizing hunter. Mar. Biol., v. 156, n. 11, p. 23552367,2009 b.

LEITE, T. S.; HAIMOVICI, M; MATHER, J; LINS-OLIVEIRA, J. E. Habitat, distribution, and abundance of the commercial octopus (Octopus insularis) in a tropical oceanic island, Brazil: Information for management of an artisanal fishery inside a marine protected area. Fish. Res., v. 98, n. 1-3, p. 85-91, 2009c.

LEITE, T. S.; BARBOSA, J. C.; ALMEIDA, L. B.; LIMA, F. D.; HAIMOVICI, M. Occurrence of Octopus insularis and observations on its feeding and mating in Trindade and Martim Vaz Archipelago of southeastern Brazil. Florianópolis: Cephalopod International Advisory Council Symposium, 2012.

LEITE, T. S.; BATISTA, A. T.; LIMA, F. D.; BARBOSA, J. C.; MATHER, J. Geographic variability of Octopus insularis diet: from oceanic island to continental populations. Aquat. Biol., v. 25, p. 17-27, 2016. 
LIMA, F. D.; LEITE, T. S.; HAIMOVICI, M.; LINS-OLIVEIRA, J. E. Gonadal development and reproductive strategies of the tropical octopus (Octopus insularis) in northeast Brazil. Hydrobiologia, v. 725, n. 1, p. 7-21, 2014a.

LIMA, F. D.; LEITE, T. S.; HAIMOVICI, M.; NÓBREGA, M. F.; LINS-OLIVEIRA, J. E. Population structure and reproductive dynamics of Octopus insularis (Cephalopoda: Octopodidae) in a coastal reef environment along northeastern Brazil. Fish. Res., v. 152, p. 86-92, 2014b.

MATHER, J. A. Factors affecting the spatial distribution of natural populations of Octopus joubini robson. Anim. Behav., v. 30, n. 4, p. 1166-1170, 1982.

MATHER, J. A. Foraging, feeding and prey remains in middens of juvenile Octopus vulgaris (Mollusca: Cephalopoda). J. Zool., v. 224, n. 1, p. 27-35, 1991.

MELO, G. A. S. Manual de identificação dos Brachyura (Caranguejos e siris) do litoral brasileiro. São Paulo: FAPESP/Pleiade, 1996.
MUNRO, C. Diving. In: ELEFTHERIOU, A. (Ed.) Methods for the study of marine benthos. 4th ed. Hoboken: John Wiley \& Sons, 2013, 496 p.

O'DOR, R. K.; WELLS, M. J. Reproduction versus somatic growth: hormonal control in Octopus vulgaris. J. Exp. Biol., v. 77, p. 1531, 1978 .

RIOS, E. Seashells of Brazil. $2^{\text {nd }}$ ed. Rio Grande: Fundação Universidade do Rio Grande. Museu Oceanográfico, 1994. 368 p.

SCHEEL, D. Characteristics of Habitats Used by Enteroctopus dofleini in Prince William Sound and Cook Inlet, Alaska. Mar. Ecol., v. 23, n. 3, p. 185-206, 2002.

SCHMIDT-NIELSEN, K. Fisiologia Animal: Adaptação e Meio Ambiente. $5^{\text {th }}$ ed. São Paulo: Santos, 1996.

SCHMITT, E. F.; SULLIVAN, K. M. Analysis of a volunteer method for collecting fish presence and abundance data in the florida keys. Bull. Mar. Sci., v. 59, n. 2, p. 404-416, 1996.

ZAR, J. H. Biostatistical Analysis. $5^{\text {th }}$ ed. New Jersey: Prentice Hall, 2010. 
